\title{
UPAYA MENINGKATKAN HASIL BELAJAR GERAK DASAR LARI DENGAN MENGGUNAKAN PENDEKATAN BERMAIN
}

\author{
Fadly Ambar Kusuma Wardana ${ }^{(1)}$ Hanik Liskustyawati ${ }^{(2)}$ \\ ${ }^{(1)(2)}$ Universitas Sebelas Maret Surakarta
}

\begin{abstract}
ABSTRAK
Tujuan penelitian adalah "untuk mengetahui peningkatan hasil belajar Gerak Dasar Lari pada peserta didik kelas V SD Negeri 02 Karangmojo tahun pelajaran 2016/2017”.

Penelitian ini merupakan Penelitian Tindakan Kelas (PTK). Penelitian ini dilaksanakan dalam dua siklus dengan setiap siklus terdiri dari dua pertemuan. Subjek Penelitian Tindakan Kelas (PTK) ini adalah peserta didik Kelas V SD Negeri 02 Karangmojo tahun pelajaran 2016/2017. Yang berjumlah 22 peserta didik, terdiri dari 9 peserta didik putra dan 13 peserta didik putri. Teknik pengumpulan data adalah dengan observasi, tes dan hasil belajar. Validitas data menggunakan teknik triangulasi data. Analisis data menggunakan kuantitatif.

Hasil analisis yang diperoleh terdapat peningkatan pada siklus I dan siklus II yaitu hasil belajar gerak dasar lari. Hasil belajar gerak dasar lari pada siklus I diperoleh hasil nilai psikomotor yang tuntas adalah $36,35 \%$ atau 8 peserta didik, dari nilai afektif yang tuntas adalah $45,45 \%$ atau 10 peserta didik, dari nilai kognitif yang tuntas adalah $68,2 \%$ atau 15 peserta didik, dan yang tergolong dalam kategori tuntas adalah 40,9\% dengan jumlah peserta didik yang tuntas adalah 9 peserta didik. Pada siklus II terjadi peningkatan presentase hasil belajar gerak dasar lari peserta didik dalam kategori tuntas sebesar 90,9\% dengan jumlah peserta didik yang tuntas adalah 20 peserta didik, dari nilai psikomotor yang tuntas adalah $72,7 \%$ atau 16 peserta didik, dari nilai afektif yang tuntas adalah 90,9\% atau 20 peserta didik, dan dari nilai kognitif yang tuntas adalah $100 \%$ atau 22 peserta didik tuntas semua.

Simpulan penelitian ini adalah penggunaan pendekatan bermain dapat meningkatkan hasil belajar gerak dasar lari pada peserta didik kelas V SD Negeri 02 Karangmojo Kec. Tasikmadu Kab. Karanganyar tahun pelajaran 2016/2017.
\end{abstract}

Kata Kunci : Hasil Belajar, gerak dasar lari, pendekatan bermain 


\section{PENDAHULUAN}

Pendidikan jasmani di sekolah dasar merupakan bagian yang tidak dapat dipisahkan dari pendidikan pada umumnya,yang bertujuan untuk membentuk atau membangun manusia dari segi lahir maupun batin (jasmani atau rohani). Segi lahir atau jasmani ini meliputi pertumbuhan dan perkembangan fisik, kesehatan dan rehabilitas. Pertumbuhan dan perkembangan fisik akan lebih cepat melalui pembelajaran jasmani. Pendidikan jasmani membentuk peserta didik mempunyai gaya hidup berolahraga sehingga menjadi perilaku hidup sehat, sedangkan rehabilitasi dalam hal ini maksudnya perbaikan sikap tubuh,misalnya sikap jalan yang kurang baik,sikap duduk yang salah dan lain- lain.

Pendidikan jasmani memiliki peran penting dalam mengintensifkan penyelenggaraan pendidikan sebagai suatu proses pembinaan manusia berlangsung seumur hidup. Pendidikan jasmani memberikan kesempatan pada siswa untuk terlibat langsung dalam aneka pengalaman belajar melalui aktivitas jasmani, bermain dan berolahraga yang dilakukan secara sistematis,terarah dan terencana. Pembekalan pengalaman belajar itu diarahkan untuk membina, sekaligus membentuk gaya hidup sehat dan aktif sepanjang hayat.

Pendidikan jasmani di sekolah dasar sangat penting bagi pertumbuhan dan perkembangan siswa. Hal ini karena pada usia 6-12 tahun pertumbuhan dan perkembangan seorang siswa sangat pesat, baik itu secara fisik maupun psikologis. Pertumbuhan secara fisik dapat ditingkatkan melalui kegiatan olahraga secara rutin. Kegiatan olahraga juga dapat merangsang tumbuhnya bakat dan minat seorang peserta didik. Pada usia anak sekolah dasar seluruh aspek perkembangan anak baik aspek kognitif, psikomotor, dan afektif mengalami perubahan. Perubahan ini mengakibatkan adanya tugas perkembangan yang harus dilakukan oleh para peserta didik. Tugas-tugas perkembangan adalah tugas-tugas yang muncul pada suatu periode 
tertentu dari kehidupan individu, yang jika berhasil akan menimbulkan rasa bahagia dan membawa arah keberhasilan dalam melaksanakan tugas-tugas berikutnya, sedangkan jika mengalami kegagalan akan menimbulkan rasa tidak bahagia,ditolak masyarakat dan kesulitan dalam menghadapi tugastugas berikutnya. Tugas-tugas perkembangan yang bersumber dari kemampuan fisik diantaranya adalah belajar berjalan, belajar melempar menangkap dan menendang bola, dan belajar menerima jenis kelamin yang berbeda dengan dirinya. Perubahan yang paling mencolok adalah pertumbuhan dan perkembangan fisik dan psikologis sehingga pendidikan jasmani disekolah dasar tidak lepas dari seorang guru yang professional yang dapat mengajarkan ilmu-ilmu atau dasar-dasar ilmu dalam berolahraga. Melalui pendidikan jasmani, guru membantu siswa dalam mengembangkan fisik dan psikologisnya. Perkembangan tersebut dilakukan dengan melakukan gerakan-gerakan dasar dalam aktivitas olahraga. Contoh gerakan dasar itu dapat kita lihat dalam suatu cabang olahraga di pendidikan jasmani yang ada disekolah dasar. Cabang olahraga tersebut diantaranya,: atletik, senam, permainan bola besar (sepak bola, basket, voli), dan permainan bola kecil (kasti, rounders, tenis meja, kipers).

Atletik merupakan gabungan dari beberapa jenis olahraga yang secara garis besar dapat dikelompokkan menjadi lari,lempar dan lompat. Dalam olah raga atletik cabang lari meliputi lari jarak dekat, lari jarak menengah, lari jarak jauh, lari estafet, dan lari gawang. Lari jarak pendek dikenal juga dengan sebutan lari cepat atau sprint. Dalam olahraga lari cepat atau sprint, pelari melakukan gerakan lari dengan kecepatan tinggi atau maksimal sepanjang jarak yang ditempuh. Dalam lari jenis ini kecepatan maksimal dari start sampai finish merupakan hal yang utama. Oleh karena itu, kekuatan fisik yang prima mutlak dimiliki oleh setiap pelari jarak pendek atau sprint. Selain itu latihan kecepatan juga diperlukan untuk mendapatkan kecepatan lari 
yang maksimal dan belatih melakukan gerakan-gerakan lari agar mendapatkan hasil yang memuaskan. Kebanyakan dari peserta didik sekolah dasar sangat menyukai olahraga lari dengan dikombinasikan kedalam suatu permainan atau kompetisi. Namun ada juga peserta didik yang merasa malas atau merasa bosan dengan model pembelajaran yang terkesan monoton, sehingga menurut peserta didik sekolah dasar olahraga lari menjadi olahraga yang paling melelahkan dan menjenuhkan. Dengan adanya masalah yang sering di hadapi dalam pembelajaran lari di sekolah dasar, sebagai guru yang professional harus bisa menemukan cara bagaimana pembelajaran olahraga lari dapat berjalan sesuai yang diinginkan dan peserta didik merasa senang ketika melakukan kegiatan olahraga tanpa ada paksaan.

Pembelajaran kecepatan lari sendiri ada dalam pembelajaran di kelas V SD semester ganjil. Untuk pembelajaran latihan kecepatan lari dibutuhkan cara mengajar yang tepat,salah satu kompetensi dasar yang harus di capai dalam mata pelajaran Penjasorkes untuk peserta

didik kelas V adalah "Mempraktikkan latihan dasar kebugaran jasmani serta nilai percaya diri, disiplin, Kejujuran, dan Kerja keras." dengan materi pokok latihan kecepatan.

Lari cepat memerlukan kecepatan lari yang maksimal dan pengetahuan tentang gerak dasar lari,diantaranya : sikap awal (saat di garis start), sikap saat berlari (posisi badan,arah pandangan, gerakan ayunan lengan, gerakan langkah kaki), dan sikap akhir saat sampai ke garis finish. Jika masalah yang ada di dalam pembelajaran kecepatan lari ini belum dapat diatasi dengan benar maka pembelajaran di kelas akan menjadi sia-sia dan tidak akan memenuhi hasil yang baik bagi peserta didik maupun guru itu sendiri, dengan kata lain seorang guru harus bisa memecahkan masalahnya dengan cara menggunakan pendekatan bermain yang dibutuhkan dalam pembelajaran gerak dasar lari.

Masalah yang ada dalam pembelajaran gerak dasar lari itu saya temukan ketika saya sedang melakukan observasi di SDN 02 
Karangmojo, ketika materi gerak dasa lari cepat diberikan kepada peserta didik kelas IV, banyak peserta didik yang belum dapat melakukan gerakan lari dengan benar dan bersungguh-sungguh, hal ini ditunjukkan ketika saya melakukan observasi di sekolah dasar tersebut,dengan nilai KKM 70 dari 22 peserta didik yang terdiri dari 9peserta didik putra dan 13 peserta didik putri, dari jumlah 22 peserta didik hanya ada 6 peserta didik yang tuntas,sedangkan lainya belum tuntas karena ada beberapa kendala antara lain, peserta didik kurang bersungguh-sungguh dalam melakukan gerak dasar lari, pembelajaran yang masih monoton membuat peserta didik bermalasmalasan untuk mengikuti pembelajaran, dan gerakan yang dilakukan masih belum memenuhi batas kriteria ketuntasan. Ditinjau dari pelaksanaan pembelajaran Penjasorkes dengan materi kecepatan lari di SDN 02 Karangmojo kurang berjalan dengan baik, serta masih ada permasalahan yang di hadapi diantarannya yaitu, peserta didik kurang mampu melakukan gerak dasar lari cepat dengan benar, sehingga peserta didik tersebut belum mendapatkan hasil yang memuaskan karena masih kurang memperhatikan gerakan lari yang mereka lakukan masing-masing. Sebagian peserta didik merasa malas untuk melakukannya, mereka beranggapan bahwa olahraga lari adalah olahraga yang membosankan dan paling melelahkan karena pembelajarannya kurang menarik. Untuk mensiasati hal tersebut saya sebagai calon guru harus mencari solusi untuk memecahkan masalah yang ada dalam pembelajaran kecepatan lari dengan cara menggunakan pendekatan bermain pada pembelajaran gerak dasar lari cepat dengan benar agar peserta didik mampu memaksimalkan gerakan larinya. Dengan adanya pendekatan bermain pada pembelajaran gerak dasar lari, peserta didik diharapkan tertarik dan menyukai pembelajarannya agar dapat melakukan gerakan larinya dengan benar dan mendapatkan hasil yang memuaskan. Namun kita harus memperhatikan alat bantu yang kita gunakan untuk pendekatan bermain 
ini dari segi keamanan dan kenyamanan, agar peserta didik merasa aman dan nyaman saat melakukan kegiatan pembelajaran.

Sejalan dengan hal tersebut, peneliti mencoba melakukan pembelajaran dengan menggunakan pendekatan bermain. Pendekatan bermain ini diharapkan bisa menjadi daya tarik bagi peserta didik terhadap pembelajaran pendidikan jasmani dengan materi kecepatan lari, sehingga peserta didik akan tertarik dan termotivasi dalam mengikuti proses pembelajarannya. Untuk mengetahui hal tersebut maka perlu dilakukan penelitian yang berkaitan dengan pendekatan bermain.

Melihat permasalahan dan kendala diatas, maka terdapat suatu pemikiran yang muncul yaitu perlunya sebuah modifikasi media pembelajaran alternatif guna sebagai alat peraga pengganti media cakram asli yang mungkin di setiap sekolah jumlahnya terbatas karena harganya yang cukup mahal. Modifikasi media pembelajaran tersebut diharapkan peserta didik menjadi lebih tertarik serta dapat membuat peserta didik lebih aktif dan antusias untuk sering mencoba agar peserta didik lebih mudah menguasai materi yang diajarkan dalam proses pembelajaran. Dengan lebih aktifnya peserta didik dalam proses pembelajaran diharapkan adanya peningkatan hasil belajar peserta didik agar mampu tercapainya tingkat ketuntasan KKM yang maksimal.

\section{METODE}

Penelitian ini merupakan Penelitian Tindakan Kelas (PTK). Penelitian Tindakan Kelas ini dilaksanakan di bulan November 2016. Subjek penelitian ini adalah peserta didik kelas V SD Negeri 02 Karangmojo. Dengan jumlah 22 peserta didik yaitu 9 peserta didik putra dan 13 peserta didik putri. Sumber data diperoleh dari Guru dan peserta didik. Teknik pengumpulan data dalam Penelitian Tindakan Kelas (PTK) ini terdiri atas tes dan observasi. Tes dipergunakan sebagai teknik pengumpulan data untuk mengukur kemampuan peserta didik dalam aspek kognitif atau tingkat penguasaan materi pembelajaran lempar cakram. Observasi 
dipergunakan sebagai teknik untuk mengumpulkan data tentang hasil belajar lempar cakram peserta didik dan tentang aktivitas peserta didik selama mengikuti proses pembelajaran melalui penerapan modifikasi media pembelajaran.

\section{HASIL DAN PEMBAHASAN}

Berdasarkan hasil data awal sebelum diberikan tindakan, maka dapat dijelaskan Kemampuan ratarata peserta didik kelas V SD Negeri 02 Karangmojo dari jumlah 22 peserta didik hanya 6 peserta didik atau $27,27 \%$ yang mampu mencapai batas ketuntasan, sedangkan 17 peserta didik atau $72,73 \%$ peserta didik lainnya masih salah dalam menguasai gerak dasar lari atau belum mencapai batas ketuntasan sesuai Kriteria Ketuntasan Minimal (KKM).

Melalui deskripsi data awal yang telah diperoleh menunjukkan kriteria keberhasilan pembelajaran yang kurang. Maka disusun sebuah tindakan untuk meningkatkan hasil belajar gerak dasar lari pada peserta didik kelas V SD Negeri 02 Karangmojo dengan menggunakan pendekatan bermain. Pelaksanaan tindakan dilakukan sebanyak 2 siklus, yaitu masing-masing siklus terdiri atas 4 tahapan, yaitu: (1) Perencanaan, (2) Pelaksanaan Tindakan, (3) Observasi, Refleksi.

\section{SIKLUS I}

Ketika pelaksanaan tindakan I, peneliti bersama guru PJOK melakukan penilaian terhadap proses pembelajaran peserta didik yang digunakan sebagai data penelitian. Deskripsi data yang di ambil oleh peneliti adalah tes unjuk kerja / tes praktik, (aspek psikomotor / keterampilan, kognitif / pengetahuan, dan afektif / sikap) peserta didik kelas V SD Negeri 02 Karangmojo tahun pelajaran 2016/2017.

Hasil belajar gerak dasar lari setelah diberi tindakan I berupa pendekatan bermain. Proses pembelajaran peserta didik seselesainya pemberian tindakan I menunjukan bahwa hasil yang didapat belum sesuai dengan harapan yaitu $80 \%$,sedangkan hasil yang di dapat peserta didik baru 40,9\% atau 9 peserta didik dari 22 peserta didik. 
Berdasarkan tes yang diberikan trik-trik untuk dilakukan pada akhir pembelajaran siklus I diketahui bahwa masih terdapat kekurangan dari target yang ditentukan, maka pembelajaran akan direvisi dan dilakukan revisi perencanaan, pelaksanaan revisi perencanaan, observasi pelaksanaan revisi perencanaan, evaluasi dari hasil pelaksanaan revisi perencanaan, dan refleksi dari revisi perencanaan. Kegiatan ini dilaksanakan agar capaian dari hasil belajar lempar cakram dapat sesuai dengan target yang disepakati, sehingga pembelajaran dilanjutkan pada siklus berikutnya.

\section{SIKLUS II}

Pada siklus II yang merupakan tindak lanjut dan perbaikan formula dari hasil analisis dan refleksi pada siklus I, yang mana pada siklus I diketahui bahwa hasil belajar mengalami peningkatan dan akan tetapi masih belum mencapai target yang di targetkan.

Dalam rencana pelaksanaan tindakan siklus II tidak jauh beda dengan pelaksanaan tindakan siklus I, hanya saja dalam siklus II

\section{PERBANDINGAN \\ ANTAR SIKLUS \\ Perbandingan hasil belajar lempar cakram pada perserta didik}


kelas V SD Negeri 02 Karangmojo tahun pelajaran 2016/2017 pada akhir siklus I dan IIyaitu:

1. Ketuntasan pada siklus I sebanyak 9 perserta didik dan meningkat pada siklus II menjadi 20 perserta didik yang mencapai ketuntasan.

2. Dalam prosentase dapat disajikan dengan data ketuntasan siklus I sebanyak 40,9\% dan meningkat pada siklus II menjadi 90,9\%.

\section{SIMPULAN, IMPLIKASI DAN}

\section{SARAN}

\section{Simpulan}

Berdasarkan analisis yang telah dilakukan dan pembahasan yang telah diungkapkan pada bab IV, diperoleh hasil penelitian sebagai berikut: Pada prasiklus, hanya 6 peserta didik yang tuntas $(27,27 \%)$ dan 17 peserta didik lainnya belum tuntas (72,72\%). Pada siklus I diperoleh hasil nilai psikomotor yang tuntas adalah $36,35 \%$ atau 8 peserta didik, dari nilai afektif yang tuntas adalah 45,45\% atau 10 peserta didik, dari nilai kognitif yang tuntas adalah $68,2 \%$ atau 15 peserta didik, dan yang tergolong dalam kategori tuntas adalah 40,9\% dengan jumlah peserta didik yang tuntas adalah 9 peserta didik. Pada siklus II terjadi peningkatan presentase hasil belajar gerak dasar lari peserta didik dalam kategori tuntas sebesar 90,9\% dengan jumlah peserta didik yang tuntas adalah 20 peserta didik, dari nilai psikomotor yang tuntas adalah $72,7 \%$ atau 16 peserta didik, dari nilai afektif yang tuntas adalah 90,9\% atau 20 peserta didik, dan dari nilai kognitif yang tuntas adalah $100 \%$ atau 22 peserta didik tuntas semua.

Berdasarkan analisis diatas diperoleh simpulan bahwa penggunaan pendekatan bermain dapat meningkatkan hasil belajar gerak dasar lari pada peserta didik kelas V Sekolah Dasar Negeri 02 Karangmojo tahun pelajaran 2016/2017.

\section{Implikasi}

Dengan demikian, implikasi penelitian tindakan kelas ini adalah:

1. Penelitian ini memberikan suatu gambaran yang jelas bahwa 
keberhasilan

proses

pembelajaran tergantung pada

beberapa faktor. Faktor-faktor

tersebut berasal dari pihak guru

maupun peserta didik serta

alat/media pembelajaran yang

digunakan. Faktor dari pihak

guru yaitu kemampuan guru

dalam mengembangkan materi,

kemampuan guru dalam

menyampaikan materi,

kemampuan guru dalam

mengelola kelas, metode yang

digunakan guru dalam proses

pembelajaran, pendekatan

pembelajaran yang tepat sesuai

materi ajar, serta teknik yang

digunakan guru sebagai sarana

untuk menyampaikan materi.

Sedangkan faktor dari peserta

didik yaitu minat dan motivasi

peserta didik dalam mengikuti

pembelajaran.

2. Memberikan deskripsi yang jelas bahwa dengan penggunaan pendekatan bermain dapat meningkatkan hasil belajar gerak dasar lari, sehingga penelitian ini dapat digunakan sebagai suatu pertimbangan bagi guru penjas untuk meningkatkan keterampilan gerak dasar lari peserta didik dalam olahraga permainan lainya dengan penerapan modifikasi permainan sederhana.

3. Dengan penggunaan pendekatan bermain dapat meningkatkan hasil belajar gerak dasar lari peserta didik, sehingga peserta didik memperoleh pengalaman baru dan berbeda dalam proses pembelajaran penjasorkes biasanya. Pembelajaran Penjasorkes yang pada awalnya membosankan bagi peserta didik, menjadi pembelajaran yang menarik dan menyenangkan bagi peserta didik.

4. Penggunaan pendekatan bermain terbukti dapat meningkatkan hasil belajar gerak dasar lari peserta didik dalam pelajaran penjasorkes maka mempengaruhi pula hasil belajar peserta didik secara keseluruhan sehingga meningkatkan kualitas sekolahan tersebut.

5. Penggunaan pendekatan bermain menjadikan peserta didik lebih antusias dan aktif dalam pembelajaran, karena pada dasarnya dunia anak adalah dunia 
bermain sehingga mereka merasa

berada dalam dunianya.

\section{Saran}

Berdasarkan simpulan dan implikasi hasil penelitian yang telah dikemukakan di atas, maka peneliti menyarankan kepada guru penjasorkes Sekolah Dasar Negeri 02
Karangmojo Kecamatan Tasikmadu Kabupaten Karanganyar untuk menggunakan pendekatan bermain sebagai alternatif inovasi pembelajaran penjasorkes demi peningkatan hasil belajar di Sekolah Dasar Negeri 02 Karangmojo Kecamatan Tasikmadu Kabupaten Karanganyar. 


\section{DAFTAR PUSTAKA}

Agus Kristiyanto. (2010). Penelitian Tindakan Kelas (PTK) Dalam Pendidikan Jasmani \& Kepelatihan Olahraga. Surakarta : UNS Press

Asep Jihad \& Abdul Haris. (2012). EvaluasiPembelajaran. Yogyakarta: Multi Pressindo.

Benny A. Pribadi. (2011). Model Desain Sistem Pembelajaran. Jakarta: Dian Rakyat.

Dani Wardani. (2009). Bermain Sambil Belajar. Jakarta: Edukasia

Dikdik Zafar Sidik. (2010). Mengajar dan Melatih Atletik: Bandung : Remaja Rogdakarya.

Dimyati \& Mudjiono. (2009). Belajar dan Pembelajaran. Jakarta: Rineka Cipta.

Dini Rosdiani. (2014). Perencanaan Pembelajaran dalam Pendidikan Jasmani dan Kesehatan. Bandung: Alfabeta.

Fadlilah. (2014). Edutainment Pendidikan Anak Usia Dini. Jakarta : Kencana Prenadamedia Group.

Giri Wiarto. (2013). Atletik. Semarang: Graha Ilmu.

M. Furqon Hidayatullah. (2008). Mendidik Anak dengan Bemain.Buku Pegangan Guru Penjas Sekolah Dasar. Universitas Sebelas Maret

M. Sobry Sutikno. (2013). Belajar dan Pembelajaran. Lombok: Holistica.

Muhajir. (2007). Pendidikan jasmani Olahraga dan kesehatan. Bandung: Erlangga

Munasifah. (2008). Atletik Cabang Lompat. Semarang: Aneka Ilmu

Nunuk Suryani\& Leo Agung. (2012). StrategiBelajarMengajar. Yogyakarta: Penerbit Ombak

Purwanto. (2011). Evaluasi Hasil Belajar. Yogyakarta: Pustaka Pelajar.

Sukirno. (2011). Belajar dan Berlatih Atletik. Depok: Arya Duta

Yudha M. Saputra. (2001). Dasar-Dasar Keterampilan Atletik Pendekatan Bermain untuk Sekolah Lanjutan Tingkat Pertama. Jakarta: Depdiknas. Direktorat Jendral Pendidikan Dasar dan Menengah. Bekerjasama dengan Direktorat Jendral Olahraga. 